\title{
Polycyclic Aromatic Hydrocarbon Increases mRNA Level for Interleukin 1 Beta in Human Fibroblast-Like Synoviocyte Line via Aryl Hydrocarbon Receptor
}

\author{
Ayako TAmaki, ${ }^{a}$ Hidetoshi Hayashi, ${ }^{a}$ Hironori NAKaJima, ${ }^{a}$ Takemasa TAKII, ${ }^{a}$ Daichi Katagiri, ${ }^{a}$ \\ Keiji MiYazawa, ${ }^{b}$ Kunitaka Hirose, ${ }^{c}$ and Kikuo OnOzaKI ${ }^{*, a}$ \\ ${ }^{a}$ Department of Molecular Health Sciences, Graduate School of Pharmaceutical Sciences, Nagoya City University; \\ Mizuho, Nagoya 467-8603, Japan: ${ }^{b}$ Central Research Laboratories, Kissei Pharmaceutical Co., Ltd.; Nagano 399-8304, \\ Japan: and ${ }^{c}$ Molecular Cell Biology Team, Biomedical Research Laboratories, Kureha Chemical Ind. Co., Ltd.; Shinjuku- \\ ku, Tokyo 169-8503, Japan. Received November 7, 2003; accepted December 12, 2003
}

\begin{abstract}
Rheumatoid arthritis (RA) is characterized by proliferation of synoviocytes that produce proinflammatory cytokines, which is implicated in the pathogenesis of the disease. Among the cytokines, IL-1 is the critical mediator of the disease. When human fibroblast-like synoviocytes line, MH7A, was treated with 3-methylcholanthrene (3-MC), a polycyclic aromatic hydrocarbon (PAH), mRNA of IL-1 $\beta$ was up-regulated. MH7A cells express functional aryl hydrocarbon receptor (AhR) as shown by 3-MC-inducible CYP1A1 mRNA expression. The effect of 3MC was inhibited by $\alpha$-napthoflavone, an AhR antagonist, indicating that the effect of 3-MC is mediated via AhR. Benzo[a]pyrene $(\mathrm{B}[a] \mathrm{P})$ and 2,3,7,8-tetrachlorodibenzo-p-dioxin (TCDD) also up-regulated mRNA level of IL-1 $\beta$ in the cells via AhR. As PAHs are much contained in cigarette smoke, these findings provide the possible basis for epidemiological studies indicating a strong association between heavy cigarette smoking and outcome of RA.
\end{abstract} ing

Key words rheumatoid arthritis; synoviocytes; IL-1; polycyclic aromatic hydrocarbon; aryl hydrocarbon receptor (AhR); smok-

Rheumatoid arthritis (RA), a chronic inflammatory condition affecting several joints, is characterized by proliferation of synoviocytes in inflamed synovia and production of proinflammatory cytokines and chemokines by synoviocytes. ${ }^{1)}$ These cytokines are implicated in the disease pathogenesis, such as production of proteases and reactive oxygen intermediates, proliferation of synovial fibroblasts, cartilage degradation, infiltration of inflammatory cells and angiogenesis. ${ }^{2,3}$ Fibroblast-like synoviocytes are major cells producing the cytokines. Fibroblast-like synoviocytes or SV40-transformed cell clones derived from RA patients secrete, constitutively or in response to IL- 1 or TNF $\alpha$, proinflammatory cytokines, including IL- $1 \alpha$, IL- $1 \beta$, IL-6 and IL-8. Among the cytokines, IL-1 is a critical cytokine involved in the disease. ${ }^{4-7}$ ) However, the mechanisms responsible for the cytokine induction remained unknown.

Polycyclic aromatic hydrocarbons (PAHs) such as 3methylcholanthrene (3-MC), benzo $[a]$ pyrene $(\mathrm{B}[a] \mathrm{P})$ and 2,3,7,8-tetrachlorodibenzo- $p$-dioxin (TCDD), environmental pollutant of great concern, cause untoward effects including carcinogenesis, teratogenesis and immune system impairment. ${ }^{8}$ Most of these effects are mediated by the aryl hydrocarbone receptor (AhR), a ligand-activated transcription factor. ${ }^{9)}$ Upon ligand-induced activation, the AhR releases its chaperoning heat shock protein 90 , translocates into the nucleus, and dimerizes with AhR nuclear translocator (ARNT). The heterodimer complex binds to DNA specific sequences called dioxin responsive elememts (DREs), and up- or downregulates the transcription of genes controlled by DREs. ${ }^{10)}$ Potential DREs are found in promoter regions of cytokines, including murine IL-1 $\beta$, IL-2, IL-5, IL-6, IL-10, TGF $\beta 1$ and IFN $\gamma \cdot{ }^{11)}$

Epidemiological studies revealed an association of cigarette smoking with disease outcome in patients with early inflammatory polyarthritics ${ }^{12)}$ and with increase of rheumatoid factor and nodule formation in patients with RA. ${ }^{13)}$ A strong association was also recognized between heavy cigarette smoking and RA, particularly in patients without a family history of RA. ${ }^{14)}$ However, the scientific basis supporting the hypothesis has not been documented. As PAHs are much contained in cigarette smoke, we hypothesized that the compounds may contribute to the initiation or the outcome of RA. In this study we show that $3-\mathrm{Mc}, \mathrm{B}[a] \mathrm{P}$ or TCDD increases the mRNA level of IL- $1 \beta$ in RA patient-derived SV40 T antigen-transformed human fibroblast-like synoviocyte line, MH7A, which has been shown to posses similar characteristics as parental synoviocytes. ${ }^{15,16)}$ It is a big mystery why RA has not been documented until 17 century. The relationship between the findings and the mystery is also discussed.

\section{MATERILAS AND METHODS}

Reagents RPMI 1640 was purchased from Sigma Chemical Co. (St. Louis, MO, U.S.A.); fetal bovine serum (FBS) was from JRH Biosciences (Lenexa, KS); 3-MC, $\mathrm{B}[a] \mathrm{P}, \mathrm{TCDD}$ and $\alpha$-napthoflavone were from Sigma Chemical Co. (St. Louis, MO, U.S.A.). Primers used for RT-PCR were purchased from Japan Genetic Institute (Sendai, Japan).

Cell Culture MH7A cells is an immortalized cell line by stably transfecting rheumatoid fibroblast-like synoviocyte cells with SV40 T antigen gene. They have already reached over 150 population doublings through culture crisis, and have been growing rapidly. MH7A cells express IL-1 receptor, intercellular adhesion molecule-1 (ICAM-1), CD16, CD40, CD80 and CD95. IL-1 $\beta$ enhanced the production of IL-6 and stromelysin-1, and the surface expression of ICAM1 , in a manner similar to that in the parental cells. ${ }^{15)}$ The cells were cultured in RPMI 1640, $100 \mathrm{U} / \mathrm{ml}$ of penicillin $\mathrm{G}$, $100 \mu \mathrm{g} / \mathrm{ml}$ of streptomycin, $15 \mathrm{~mm}$ HEPES and 5\% heat-inac- 
(A)

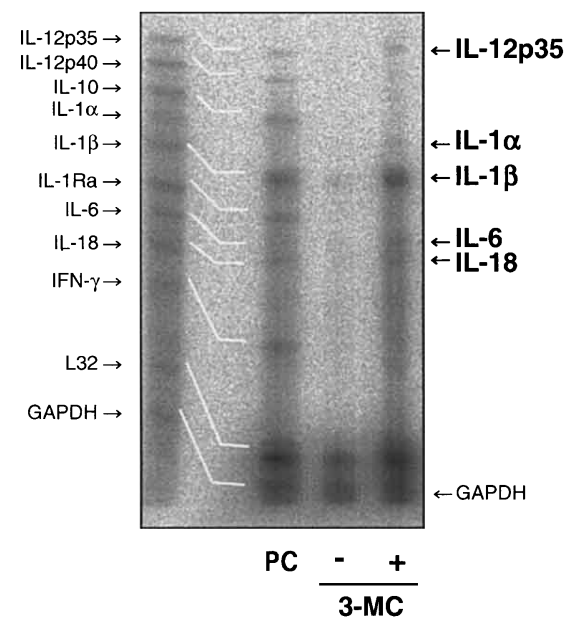

(B)

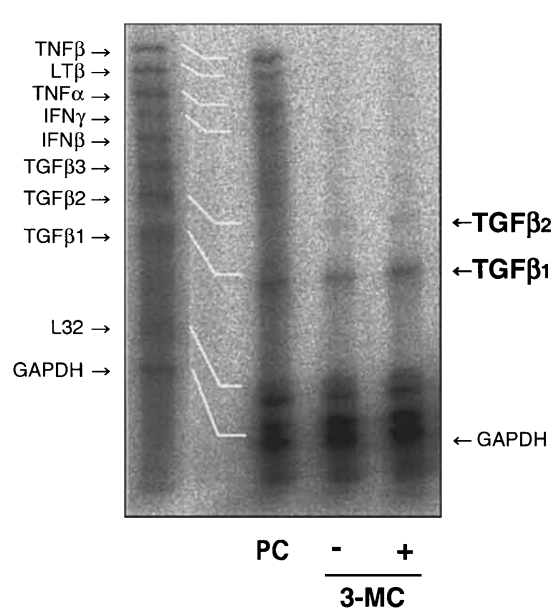

(C)

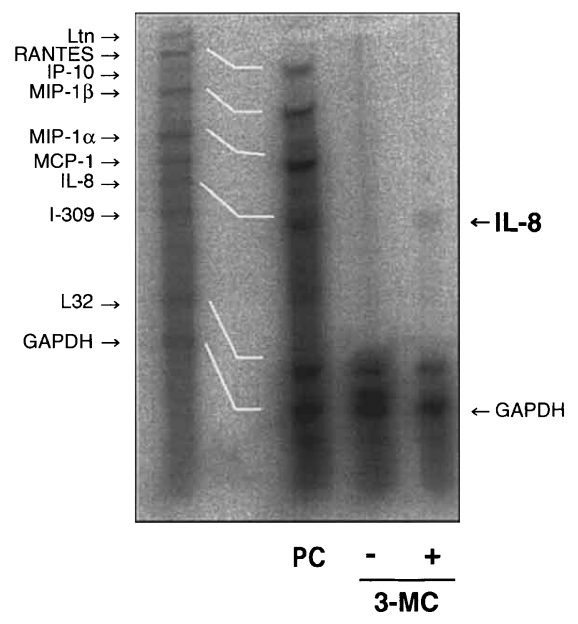

PC : positive control

Fig. 1. Effect of 3-MC on mRNA Levels of Proinflammatory Cytokines

Cells were treated for $4 \mathrm{~h}$ with or without $3-\mathrm{MC}(0.1 \mu \mathrm{M})$. Then total RNA was extracted, and expression level of cytokines was determined by RNase protection assay. The data shown were representative of three independent experiments with similar results.

tivated FBS at $37^{\circ} \mathrm{C}$.

RNA Preparation and Reverse Tanscriptase (RT) Reaction Total RNA from cells was extracted according to the method of P. Chomczynski and N. Sacchi. ${ }^{17)}$ The amount of RNA was determined by spectrophotometrically. The RT reaction was performed by incubating $2 \mu \mathrm{g}$ of total RNA in $20 \mu \mathrm{l}$ reaction volume containing $50 \mathrm{~mm}$ Tris $-\mathrm{HCl}(\mathrm{pH} 8.3)$, $40 \mathrm{~mm} \mathrm{KCl} 6 \mathrm{~mm} \mathrm{MgCl}_{2}, 10 \mathrm{~mm}$ DTT, $0.5 \mathrm{~mm}$ dNTP, $40 \mathrm{ng}$ Random Primer $\mathrm{p}(\mathrm{dN}) 6,6 \mathrm{U}$ ribonuclease inhibitor and $40 \mathrm{U}$ M-MLV Reverse Transcriptase. The reaction mixtures were incubated at $37^{\circ} \mathrm{C}$ for $60 \mathrm{~min}$, followed by at $70^{\circ} \mathrm{C}$ for $10 \mathrm{~min}$ in Pogram Temp control system PC-700 (ASTEC). The reaction mixtures were diluted to five fold of volume with $\mathrm{ddH}_{2} \mathrm{O}$ and used as cDNA solution. cDNA samples were stored at $4{ }^{\circ} \mathrm{C}$ until PCR analysis.

PCR Analysis Primers used for human IL- $1 \beta$ were $5^{\prime}$ ATGGCAGAAGTACCTGAGCTC-3' and 5'-TTAGGAAGACACAAATTGCATGGTGAAGTCAGT-3', for human CYP1A1 were 5'-TCCAGAGACAACAGGTAAAACA-3' and 5'-AGGAAGGGCAGAGGAATGTGAT-3', and for human GAPDH were 5'-TGAAGGTCGGAGTCAACGGATTTGGT-3' and 5'-CATGTGGGCCATGAGGTCCACCAC- $3^{\prime}$. PCR reactions contained $1 \times$ PCR buffer, $0.4 \mathrm{~mm}$ dNTPs, $2.5 \mathrm{ng}$ forward and reverse primers, 0.005 U Ampli Taq Gold ${ }^{\mathrm{TM}}$ DNA Polymerase (Perkin Elmer), and $5 \mu \mathrm{l}$ cDNA solution in a $10 \mu \mathrm{l}$ volume. IL- $\beta$ cDNAs were amplified for 25 cycles, of $94^{\circ} \mathrm{C}$ (denaturation) for $1 \mathrm{~min}, 54^{\circ} \mathrm{C}$ (annealing) for $1 \mathrm{~min}$, and $72^{\circ} \mathrm{C}$ (primer extension) for $1 \mathrm{~min}$. CYP1A1 and GAPDH cDNAs were amplified for 26 and 24 cycles, respectively, of $94^{\circ} \mathrm{C}$ (denaturation) for $1 \mathrm{~min}$, $56^{\circ} \mathrm{C}$ (annealing) for $1 \mathrm{~min}$, and $72^{\circ} \mathrm{C}$ (primer extension) for $1 \mathrm{~min}$. PCR products $(5 \mu \mathrm{l})$ were analyzed on $1.5 \%$ agarose gels in the presence of ethidium bromide. Fragments of 810 bps (IL-1 $\beta, 88$ - 897), 371 bps (CYP1A1, 1857-2227), and $983 \mathrm{bps}$ (GAPDH, 86-1068) were generated, the restriction endonuclease patterns of each of which were consistent with those of the respective genes. Experiments were conducted three times.
RNase Protection Assay Total RNA $(1 \mu \mathrm{g})$ extracted from each sample was hybridized to ${ }^{32} \mathrm{P}$-labeled multple cytokine gene probes using a ribonuclease protection assay kit (PharMingen, San Diego, CA, U.S.A.). The protected RNAs were separated on a polyacrylamide gel. The gel was dried and autoradiographed to detect specific bands by Bio-image analyzer BAS2500 (Fuji Photo Film, Tokyo, Japan).

\section{RESULTS}

3-MC Increases mRNA Level of IL-1 $\beta$ in MH7A Synovial Cells In order to examine whether 3-MC induces cytokines from MH7A cells, the cells were treated with 3-MC, and then mRNA levels of a variety of cytokines were determined by RNase protection assay (Fig. 1). The assay revealed that the expression levels of mRNA of IL- $1 \alpha$, IL- $1 \beta$, IL-6, IL-12p35 and IL-18, but not IL-8, TGF $\beta 1$ and TGF $\beta 2$, were up-regulated by the treatment with 3-MC when normalized with the level of GAPDH. Among these cytokines, IL- $\beta$ mRNA was most markedly and consistently up-regulated by 3-MC.

We then examined in more detail the effect of 3-MC on mRNA expression level of IL- $1 \beta$ in MH7A cells by RT-PCR method. When the cells were treated with $3-\mathrm{MC}$ at $0.1 \mu \mathrm{M}$, mRNA level of IL- $1 \beta$ increased at $2 \mathrm{~h}$, the level was sustained for $8 \mathrm{~h}$, decreased at $15 \mathrm{~h}$, and again increased at $24 \mathrm{~h}$ (Fig. 2A). Next, we determined the dose-dependent effect of 3-MC. At either $4 \mathrm{~h}$ or $24 \mathrm{~h}$, the mRNA level was up-regulated by $3-\mathrm{MC}$ at more than $0.01 \mu \mathrm{M}$ (Fig. 2B). At $24 \mathrm{~h}$, however, the mRNA level did not increase at $10 \mu \mathrm{M}$, which may be due to toxicity of 3-MC. The vehicle alone did not affect the mRNA level (data not shown).

As it was concerned about the contamination of endotoxin in 3-MC, we treated the cells with LPS $(100 \mathrm{ng} / \mathrm{ml})$ and 3$\mathrm{MC}(0.1 \mu \mathrm{M})$ in the presence or absence of Polymyxin B. LPS up-regulated mRNA level of IL- $1 \beta$. However, the LPSinduced increase was completely inhibited by Polymyxin B, while Polymyxin B did not affect the effect of 3-MC (data 
(A)

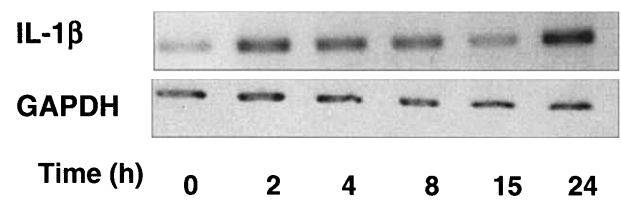

(B)

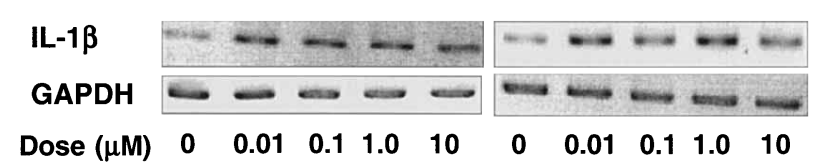

(C)

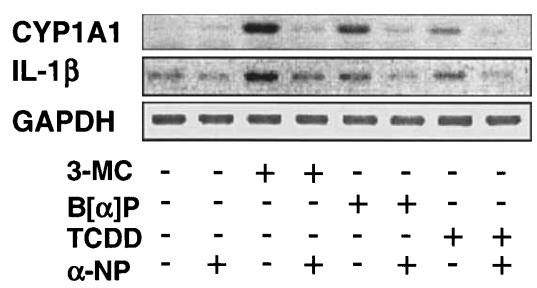

Fig. 2. Effect of 3-MC, B[a]P, TCDD or $\alpha$-NF on mRNA Expression Level of IL- $1 \beta$ in MH7A Cells

Cells were treated for indicated period with $3-\mathrm{MC}(0.1 \mu \mathrm{M})$ (A) or treated for $4 \mathrm{~h}$ and $24 \mathrm{~h}$ with or without varying doses of 3-MC (B). Cells were also treated with 3-MC $(0.1 \mu \mathrm{M}), \mathrm{B}[a] \mathrm{P}(1 \mu \mathrm{M})$ or TCDD $(5 \mu \mathrm{M})$ with or without $\alpha-\mathrm{NF}(5 \mu \mathrm{M})$ for $4 \mathrm{~h}(\mathrm{C})$. Al the experiments were performed in the presence of Polymyxin B $(10 \mu \mathrm{g} / \mathrm{ml})$. Total RNA was extracted, and expression levels of mRNA of IL-1 $\beta$, CYP1A1 and GAPDH were determined by RT-PCR method. Representative data of three independent experiments with similar results were shown.

not shown), indicating that the $3-\mathrm{MC}$ effect was not due to endotoxin contamination. In addition, 3-MC preparation was endotoxin-free according to the Limulus amoebocyte assay (sensitivity limit of $0.1 \mathrm{ng} / \mathrm{ml}$ ).

3-MC, B $[a]$ P or TCDD Increases mRNA Level of IL-1 $\beta$ via AhR In order to determine whether augmenting effect of 3-MC is mediated by AhR, MH7A cells were treated with or without $3-\mathrm{MC}$ in the presence or absence of $\alpha$ napthoflavone $(\alpha-\mathrm{NF})$, an antagonist for $\mathrm{AhR},{ }^{18)}$ for $4 \mathrm{~h}$, and mRNA level of IL- $1 \beta$ was determined by RT-PCR method. As a positive gene responsive to AhR activation, mRNA of CYP1A1 was also determined. As shown in Fig. 2C, mRNA level of CYP1A1 was up-regulated by 3-MC. $\alpha$-NF alone did not induce CYP1A1 mRNA, but it inhibited the augmenting effect of 3-MC. We also examined whether $\mathrm{B}[a] \mathrm{P}$ or TCDD up-regulates expression level of IL- $\beta$ mRNA. mRNA levels of CYP1A1 and IL- $1 \beta$ were also up-regulated by $\mathrm{B}[a] \mathrm{P}$ or TCDD, and these effects were inhibited by $\alpha$-NF. Vehicle alone did not show any effect (data not shown).

\section{DISCUSSION}

In this study we showed that 3-MC up-regulated mRNA level of IL-1 $\beta$ in human fibroblast-like synoviocyte line MH7A. 3-MC up-regulated biphasically mRNA level of IL$1 \beta$ in the cells. The up-regulation at $24 \mathrm{~h}$ may be due to a secondary effect of 3-MC-induced molecules. 3-MC at more than $0.01 \mu \mathrm{m}$ augmented the expression of IL- $1 \beta$ mRNA. At high dose, however, 3-MC did not exhibit the augmenting effect at $24 \mathrm{~h}$, which may be due to the toxic effect of 3-MC.
A major signaling pathway for PAHs consists of AhR/ ARNT heterodimer and its responsive DREs in the promoter region of inducible genes. ${ }^{9,10)}$ Potential DREs were found in promoter region of several murine cytokines, including IL$1 \beta$, IL-2, IL-5, IL-6, IL-10, TGF $\beta 1$ and IFN $\gamma \cdot{ }^{11)}$ In murine thymocytes DREs in IL-2 gene were recently verified essential in an activation of IL-2 gene by TCDD. ${ }^{19)}$ We then determined whether the augmenting effect of 3-MC is mediated by AhR. 3-MC as well as $\mathrm{B}[a] \mathrm{P}$ or TCDD increased the level of CYP1A1 mRNA, which was inhibited by an antagonistic compound for AhR, $\alpha$-NF, indicating the presence of functional AhR in MH7A cells. As augmenting effect of 3-MC, $\mathrm{B}[a] \mathrm{P}$ or TCDD on IL- $1 \beta$ mRNA expression was inhibited by $\alpha$-NF, the effect was revealed to be mediated via AhR. Although the level of IL- $1 \beta$ protein in the culture supernatants of MH7 cells stimulated with PAHs for $24 \mathrm{~h}$ was below the detection limit of enzyme-linked immunosorbent assay (ELISA), about 1.5 -2fold increase of IL- $1 \beta$ protein was observed in the cell lysates (data not shown). This indicates that the amount of secreted IL- $1 \beta$ protein was very low or its secretion and maturation may require secondary stimulation.

The mechanism is not known by which PAHs induce upregulation of mRNA level of IL- $1 \beta$ in MH7A cells via AhR, because putative DREs were not found in the promoter region of human IL-1 $\beta$. First possibility is that DREs are present in the unreported region of the gene. Second possibility is that other transcription factors are activated by the genotoxic effect of aryl hydrocarbon metabolites or reactive oxygen intermediates generated from the metabolites. Final possibility is that a physical interaction of AhR with other transcription factors affects the function of the transcription factors. Recent studies revealed that AhR binds to the RelA subunit of NF- $\kappa \mathrm{B},{ }^{20)}$ estrogen receptor alpha and orphan receptors (COUP-TFI and ERRalpha1), ${ }^{21)}$ and $\mathrm{Rb}$ protein. ${ }^{22)}$ It is reported that TCDD induces mRNA expression of IL- $1 \beta$ in a human keratinocyte cell line ${ }^{23)}$ and human endometrial stromal cells. ${ }^{24)}$ Therefore, whatever the mechanism is, the augmenting effect of PAHs on IL- $1 \beta$ mRNA expression is not limited to synoviocytes.

The aberrant production of proinflammatory cytokines, especailly IL- 1 and $\mathrm{TNF} \alpha$, are implicated in the pathogenesis of RA. Studies demonstrated dramatic improvement in synovial inflammation in RA patients after treatment with neutralizing anti-TNF $\alpha$ antibody or soluble TNF receptors, ${ }^{25}$ ) and decreased joint destruction after treatment with IL-1 receptor antagonist. ${ }^{26)}$ However, it is not known how these cytokines were induced at an initial phase of the disease.

Our findings are quite interesting in considering the etiology of RA. Epidemiological studies revealed an association of cigarette smoking with disease outcome in patients with early inflammatory polyarthritics ${ }^{12)}$ and with increase of rheumatoid factor and nodule formation in patients with RA. ${ }^{13)}$ It was also reported a strong association between heavy cigarette smoking and RA, particularly in patients without a family history of RA. ${ }^{14)}$ RA has not been documented until 17 century. Guillaume Baiillou (1558-1616) assorted rheumatoid disease in relation to arthritics, and Thomas Syndenham (1624-1689) distinguished RA from the related disease, such as gout and rheumatic fever. ${ }^{27)}$ However, the reason why RA has not been documented until 17 century is a big mystery. We hypothesize that it was initiated 
by tobacco smoking. Tobacco is thought to be imported to Europe from America. Christopher Colombus discovered America in 1492. There is a first report regarding tobacco plants in Europe in 1497. In 1560 Jean Nicot, French doctor, brought the tobacco plant to Eastern Europe. In 1586 settlers from Virginia brought the tobacco smoke with the pipe to England. In 16/17-century tobacco smoking widely spread in Europe as shown by the fights against tobacco consumption in different states under threat of punishments. ${ }^{28)}$ Collectively these historical contexts support the epidemiological studies that tobacco smoking, especially heavy smoking, is a risk factor for RA. It is of note that North America Indians, among them tobacco smoking is quite popular, have high prevalence rates of $\mathrm{RA}^{29)}$ Our findings are the first to provide the possible basis for the epidemiological studies. Industrial revolution occurred thereafter in the second half of 18 century and successive motorization and synthesis of a large amount of chemicals accelerated the environmental pollution with PAHs, which presumably further contributed to the outcome of RA.

RA is a complex disease, which is influenced by the genetic factor, sex hormones and environmental factors. Infection with viruses or bacteria is presumed to be the environmental factor. ${ }^{30,31)}$ However, the infection theory cannot explain why RA has not been documented until 17 century. We hypothesize that PAHs derived from smoking, especially heavy smoking, chronically induce IL- $1 \beta$ from synovial fibroblast-like cells, although the secretion and maturation of IL- $1 \beta$ may require secondary factor. Even if the amount of IL- $1 \beta$ is low, chronic exposure to IL- $1 \beta$ causes the early inflammatory polyarthritics, which subsequently develop to RA under the influence of sex hormone and genetic factors. It is of note that swelling and pain of joints are common features in "yusho" patients caused by the ingestion of rice oil which had been accidentally contaminated with polychlorinated biphenyls (PCB), which contained TCDD. ${ }^{32}$ To determine whether similar induction of mRNA and proteins for IL-1 $\beta$ and other cytokines by PAHs is observed in other synovial cell lines and primary cultured cells will be important to substantiate our hypothesis.

Acknowledgments This work was supported in part by Grant-in-Aids for Scientific Research (B) from Japan Society for the Promotion of Science, and Grant-in-Aids for Scientific Research on Priority Areas (C) from The Ministry of Education, Culture, Sports, Science and Technology, Japan.

\section{REFERENCES}

1) Burmester G. R., Stuhlmuller B., Keyszer G., Kinne R. W., Arthritis
Rheum., 40, 5-18 (1997).

2) Arend W. P., Dayer J. M., Arthritis Rheum., 38, 151-160 (1995).

3) Szekanecz Z., Strieter R. M., Kunkel S. L., Koch A. E., Springer Semin. Immunopathol., 20, 115-132 (1998).

4) Ritchlin C., Arthritis Res., 2, 356-360 (2000).

5) Dalton B. J., Connor J. R., Johnson W. J., Arthritis Rheum., 32, 279287 (1989).

6) Bucala R., Ritchlin C., Winchester R., Cerami A., J. Exp. Med., 173, 569-574 (1991).

7) Shimozato O., Watanabe N., Goto M., Kobayashi Y., Cytokine, 8, 99 105 (1996).

8) Schmidt J. V., Bradfield C. A., Annu. Rev. Cell Dev. Biol., 12, 55-89 (1996).

9) Okey A. B., Riddick D., Harper P. A., Trends Pharmacol. Sci., 15, 226-232 (1994).

10) Wilhelmsson A., Cuthill S., Denis M., Wikstrom A. C., Gustafsson J. A., Poellinger L., EMBO J., 9, 69-76 (1990).

11) Lai Z. W., Pineau T., Esser C., Chem. Biol. Interact., 100, 97-112 (1996).

12) Harrison B. J., Silman A. J., Wiles N. J., Scott D. J., Symmons D. P., Arthritis Rheum., 44, 323-330 (2001).

13) Tuomi T., Heliovaara M., Palosuo T., Aho K., Ann. Rheum. Dis., 49, $753-756$ (1990).

14) Hutchinson D., Shepstone L., Moots R., Lear J. T., Lynch M. P., Ann. Rheum. Dis., 60, 223-227 (2001).

15) Miyazawa K., Mori A., Okudaira H., J. Biochem. (Tokyo), 124, 1153-1162 (1998)

16) Miyazawa K., Mori A., Akahane M., Ajisawa Y., Okudaira H., J. Biol. Chem., 273, 24832-24838 (1998).

17) Chomczynski P., Sacchi N., Anal. Biochem., 162, 156-162 (1987).

18) Blank J. A., Tucker A. N., Sweatlock J., Gasiewicz T. A., Luster M. I., Mol. Pharmacol., 32, 169-172 (1987).

19) Jeon M. S., Esser C., J. Immunol., 165, 6975-6983 (2000).

20) Tian Y., Ke S., Denison M. S., Rabson A. B., Gallo M. A., J. Biol. Chem., 274, 510-515 (1999).

21) Klinge C. M., Kaur K., Swanson H. I., Arch. Biochem. Biophys., 373, $163-174(2000)$

22) Puga A., Barnes S. J., Dalton T. P., Chang C., Knudsen E. S, Maie M. A., J. Biol. Chem., 275, 2943-2950 (2000).

23) Sutter T. R., Guzman K., Dold K. M., Greenlee W. F., Science, 254, 415-418 (1991).

24) Yang J. H., Biochem. Biophys. Res. Commun., 257, 259-263 (1999).

25) Elliott M. J., Maini R. N., Feldmann M., Kalden J. R., Antoni C., Smolen J. S., Leeb B., Breedveld F. C., Macfarlane J. D., Bijl H., et al., Lancet, 344, 1105-1110 (1994).

26) Jiang Y., Genant H. K., Watt I., Cobby M., Bresnihan B., Aitchison R., McCabe D., Arthritis. Rheum., 43, 1001-1009 (2000).

27) Kitajima O., "Collagen Disease $\cdot$ Rheumatoid Disease," ed. by Miyasaka N., Asakura Press, Tokyo, 2001, pp. 2-5.

28) Mahnke M., Term-Paper "Addiction"〈http://oie.mpg.uni-rostock.de/ people/reinhard.dir/home.htm $\rangle$ (1996).

29) Peschken C. A., Esdaile J. M., Semin. Arthritis. Rheum., 28, 368-391 (1999).

30) Iwakura Y., Tosu M., Yoshida E., Takiguchi M., Sato K., Kitajima I., Nishioka K., Yamamoto K., Takeda T., Hatanaka M., et al., Science, 253, 1026-1028 (1991).

31) Krause A., Kamradt T., Burmster G., Curr. Opin. Rheumatol., 8, 203-209 (1996).

32) Okumura M., Prog. Clin. Biol. Res., 137, 13-18 (1984). 